therefore decided that it was in her best interests to be enrolled in a baptism class and to be baptised as soon as she was ready. In addition, however, because he regarded confirmation as being an issue of much greater significance to $C$ he ordered that she should not be confirmed before her sixteenth birthday without her mother's consent. [Frank Cranmer]

\title{
Re St Mary, Trentham
}

Lichfield Consistory Court: Eyre Ch, 10 June 2012 Exhumation - family grave - seemly and practicable

The petitioner applied to exhume his father's ashes in order to inter his parents in the same family grave. The father had died first and his ashes had been interred in the churchyard, the petitioner not knowing that his mother wished to be buried in a family grave at Trentham Cemetery. The petition was supported by the PCC and vicar and the local authority had confirmed that there was space in the family grave. The chancellor held that any exercise of discretion to allow exhumation from consecrated ground is a two-stage process. First, the court must consider whether the matters raised are capable in law of amounting to special circumstances. Second, it must be shown that exhumation is justified in the particular circumstances of the case. The facts of this case - the 57-year marriage of the petitioner's parents, the relatively recent burial of both parties and the fact that the family grave was already established - justified exhumation in this instance. However, exhumation must also be seemly and practicable, which was made difficult by the fact that the ashes had been poured into the grave rather than interred in a casket. Following evidence from the incumbent that the ashes could be exhumed in a seemly manner without disturbing other remains it was found that exhumation was seemly and practicable and the faculty was granted. [Catherine Shelley]

doi:10.1017/So956618X12000981

\section{Re Boston Cemetery}

Lincoln Consistory Court: Bishop Ch, 18 June 2012 Exhumation - family grave

The petitioner sought a faculty for the exhumation of the cremated remains of his wife, who had been interred in a family grave containing the remains of her 